\title{
JUURNAL.RU
}

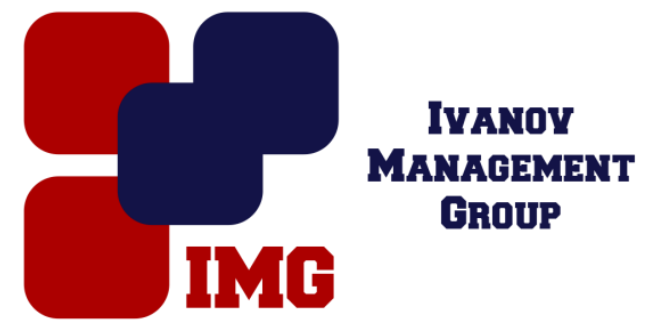

Смолина А.А., Кунин В.А., Вечеркина Ж.В. Богатырева Ю. А., Чиркова Н.В. Воронежский государственный медицинский университет имени Н. Н. Бурденко Воронеж, Россия

doi: $10.18411 / \mathrm{spc}-31-07-2017-03$

idsp 000001:spc-31-07-2017-03

\section{Превентивные мероприятия для предотвращения кариозных поражений}

Профилактика стоматологических заболеваний - вопрос, беспокоящий стоматологов нашей страны не первое десятилетие, так как не всегда была востребована у населения Российской Федерации, поэтому и уровень гигиены полости рта в целом оставался низким[7,9]. Под профилактикой подразумевают комплекс государственных, коллективных, семейных и индивидуальных мероприятий, направленных на предупреждение заболеваний и сохранность здоровья населения. Цель профилактической стоматологии - не только предупреждение болезней полости рта, но и контроль за ними, причем последний имеет первостепенное значение. По данным ВОЗ и различных авторов, распространенность стоматологических заболеваний среди детского населения достигает 75-95\%, взрослого - 100\% [6]. В возрастных группах населения старше 35 лет, проблемы, связанные с болезнями зубов и полости рта, выходят на первое место. На современном этапе лидирующие позиции по частоте стоматологической патологии занимают кариозные поражения зубов[8].

В последнее время вопросам профилактики в стоматологии уделяется особое внимание. В огромном количестве отечественных и зарубежных литературных источников можно встретить и рекомендации по осуществлению профилактических мероприятий, и научно обоснованные, доказанные на практике, современные методы и средства профилактики[1,7].Учитывая высокую распространенность стоматологических заболеваний среди населения 
и тенденцию к ее росту, по нашему мнению, необходимо создание индивидуальных организационных и методических принципов по предупреждению кариеса и реализации их на практике [4,5].

Наличие фундаментальных знаний о причинах и развитии заболеваний является необходимой предпосылкой для разработки их первичной профилактики. Наиболее эффективными являются методы профилактики, воздействующие на причину заболеваний. Выделяют экзогенные и эндогенные факторы риска возникновения кариеса зубов. Рациональный уход за полостью рта является базовым методом профилактики и может носить характер этиологический, т.е. направленный на устранение причин заболеваний органов полости рта (микроорганизмов зубных отложений).Профилактическое значение ухода за полостью рта не вызывает никакого сомнения, об этом убедительно свидетельствуют данные специального изучения стоматологического статуса в зависимости от уровня гигиены полости рта. Наглядным свидетельством профилактического значения гигиены полости рта являются исследования на добровольцах, у которых при исключении активных гигиенических мероприятий в присутствии углеводов в короткие сроки возникают множественные очаги деминерализации эмали, полностью исчезающие при последующем регулярном и тщательном уходе за зубами [6,3].

Изменение характера питания, его рационализация также является показательным примером в комплексной программе профилактики. На наш взгляд пропаганда грудного вскармливания, разъяснение роли питания, снижение употребления пищи (не более 3-4 раз в день), содержащих легко ферментированные углеводы, ограничение употребления сладких газированных напитков, употребление овощей и фруктов, содержащих витамины $\mathrm{A}, \mathrm{C}, \mathrm{E}$, исключение недоедания, несомненно играет положительную роль в стратегии сохранения стоматологического здоровья [2].

Низкая резистентность эмали к действию кислот обусловленная особенностями состава и свойств, относится к местным факторам риска. Повышение кариесрезистентности, которому способствуют хороший уровень гигиены, рацион питания хорошая жевательная нагрузка и самоочищение поверхности зубов, правильное формирование зачатков зубов и развитие тканей зуба, а также полноценное созревание эмали твердых тканей зубов после 
прорезывания, является несомненно важной частью алгоритма стоматологической профилактики $[1,6]$.

К системным факторам риска возникновения кариозных поражений можно по данным научной литературы относят алиментарный дефицит кальция в организме, низкое содержание фторидов в питьевой воде, системные хронические заболевания (сахарный диабет, ожирение, онкологические и сердечно-сосудистые заболевания, остепороз) и стрессовые воздействия $[5,6]$. Профилактические мероприятия, направленные на комплексный подход к детальной оценкеданных экзогенных причин и изучению технологий их устранения имеет наивысший уровень доказательности превенции стоматологической патологии.

Массовая стоматологическая заболеваемость влечет за собой необходимость сплошной на уровне популяции профилактики с применением таких мер, как:

- организация профилактики на государственном, региональном, учрежденческом уровнях;

- планирование профилактики, разработка специальных программ, выпуск средств профилактики в государственном масштабе;

- развитие специального раздела профилактики - гигиены полости рта;

- организация и проведение санитарно-просветительной работы, гигиенического обучения и воспитания.

Таким образом, только мультимодальныйподход с использованием таких технологий, как стимулирование мотивации в пользу стоматологического здоровья, стоматологическое просвещение (включая вопросы правильного питания), оценка факторов риска, выполнение индивидуальной и профессиональной гигиены полости рта, применение кальций и фтор содержащих средств, герметизация фиссур постоянных зубов, минимальное инвазивное лечение с полным пониманием обменных процессов в тканях зуба,может служить основой и глобальным индикатором профилактики стоматологических заболеваний вообще и кариозных поражений, в частности. 
1. Анализ профилактических мероприятий стоматологических заболеваний у детей / А.А. Смолина, В.А. Кунин, Ж.В. Вечеркина, Н. В. Чиркова / Системный анализ и управление в биомедицинских системах.- 2016.- Т.15, № 2.-С.338-341.

2. Беленова И.А. Индивидуальная профилактика кариеса у взрослых: Автореф. дис.... д-ра мед.наук. // И.А. Беленова. - Воронеж, 2010. - 48 с.

3. Дифференцированный подход к формированию у детей мотивации к проведению мероприятий по профилактике стоматологических заболеваний / А.А. Смолина [и др.] // Medicus.- 2016. № 4 (10). - C. 53-55.

4. Использование психолого - педагогических методик в качестве лечебно педагогических мероприятий на уроках физической культуры в школах / A.H. Морозов, И.В. Корецкая, С. Г. Шелковникова, Н.В. Чиркова // Научно-медицинский вестник Центрального Черноземья, 2015. - № 62. - С. 16-22.

5. Коммунальная стоматология: учебно - методическое пособие / А.Н. Морозов [и др.].Воронеж, 2016.-125 c.

6. Профилактическая стоматология: Учебник / Э.М. Кузьмина, О.О. Янушевич.- М.: Практическая медицина, 2016.- 544 с.

7. Симуляционное обучение в системе подготовки врача-стоматолога для улучшения качества стоматологической помощи / Есауленко И.Э.,Чиркова Н.В., Морозов А.Н., Вечеркина Ж.В. // Системный анализ и управление в биомедицинских системах. 2015. - T.14, №2. - C.334-337.

8. Predictive research methods of enamel and dentine for initial caries detection / A.A.Kunin [et al.] // Springer EPMA - Journal. - 2013. - Vol. 4, Suppl. 19.

9. The use of led radiation in prevention of dental diseases / МоисееваН.C., ИпполитовЮ.А.,КунинД.А., МорозовА.Н., ЧирковаН.В. / The EPMА Journal.- 2016.- Т. 7, № S 1.- C.24. 